\title{
Does political risk matter for economic and financial risks in Venezuela?
}

\author{
Dervis Kirikkaleli* (1)
}

\section{${ }^{*}$ Correspondence:}

dkirikkaleli@eul.edu.tr

Department of Banking

and Finance,

Faculty of Economic

and Administrative Science,

European University of Lefke,

Lefke, Northern Cyprus, TR-10

Mersin, Turkey

\begin{abstract}
In this paper, the time-frequency dependency of political risk as well as economic and financial risks is explored in Venezuela using quarterly data from 1984Q1 to 2018Q4. The present study uses the wavelet coherence technique, which allows the investigation of both the long and short-term causal relationships between political risk and economic and financial risks in Venezuela. The findings of this study indicate that: (i) significant vulnerabilities in political risk, economic risk, and financial risk are observed at different time periods and different frequency levels; (ii) political risk has a strong power for explaining economic risk from 1995 to 2005 in the long run, while between 1984 and 2010, economic risk and political risk are positively correlated at different frequency levels; (iii) in the long run, changes in political risk significantly lead to changes in financial risk in Venezuela.
\end{abstract}

Keywords: Political risk, Venezuela, Financial risk, Economic risk, Wavelet coherence

JEL Classifications: R11, E5, G0, P16, C60

\section{Introduction}

In the literature, scholars have paid considerable attention to political instability, underlining that there is a consensus on the adverse effect of political instability on macroeconomic dynamics. In general, the effects of an unstable political environment on an economy can occur via two channels: direct and indirect (Asteriou and Price 2001). In the direct channel, "political uncertainty changes the nature of investment and affects the demand of factors and changes the pattern of spending which has direct effect on economic growth" (Tabassam et al. 2016). The indirect channel underlines that economic growth is likely to be affected negatively by declining investments as a result of the deteriorating political environment. In addition, political uncertainty is considered as an unwanted situation for investors due to its adverse effect on economic performance because in an unstable political environment, it is difficult for entrepreneurs to accurately forecast the country's economic growth in the long run. Since political uncertainty can minimize a government's life, it narrows policymakers' horizons, hence leading to inappropriate economic policies that adversely affect the soundness of the economy and the finance sector. Recent studies by Murad and Alshyab (2019), Okafor (2017) and Sweidan (2016) have underlined that rising political tension in the domestic market is associated with decelerated economic growth.

(c) The Author(s) 2020. This article is licensed under a Creative Commons Attribution 4.0 International License, which permits use, sharing adaptation, distribution and reproduction in any medium or format, as long as you give appropriate credit to the original author(s) and the source, provide a link to the Creative Commons licence, and indicate if changes were made. The images or other third party material in this article are included in the article's Creative Commons licence, unless indicated otherwise in a credit line to the material. If material is not included in the article's Creative Commons licence and your intended use is not permitted by statutory regulation or exceeds the permitted use, you will need to obtain permission directly from the copyright holder. To view a copy of this licence, visit http://creativeco mmons.org/licenses/by/4.0/. 
Despite the effects of political instability on the economy, political instability also asserts an important influence on the financial sector of a country. In other words, rising political instability in a country is likely to deteriorate the financial system. Political turbulence is likely to affect the risk-return profile of a country and it can also boost the required rate of return of current and future investments. This situation is likely to discourage the incumbent government from reducing taxes and increasing government expenses due to the rising costs of domestic and foreign borrowing rates. Consequently, the deceleration of economic activities in the market will decrease living standards in the long term (Gunay 2016). In the literature, most empirical studies in the finance field have focused on the effect of political instability on stock markets due to the availability of data. Chan and Wei (1996) conducted a study on the Hang Seng index in Hong Kong and documented the effect of positive political news on the returns of the Hang Seng index. Their findings revealed that while positive news affected the returns positively, negative political news had a negative effect. Focusing on the Greek stock market, Alexakis and Petrakis (1991) found that there was a significant relationship between political indicators and the performance of the Greek stock market index. As stated by the study of Barro (1991), in periods of political turbulence, entrepreneurs with a risk-averse perspective are likely to shift their investments to other countries that offer more relative safety and less risk. More recent studies by Wang (2019), Hillier and Loncan (2019) and Charfeddine and Al Refai (2019) have indicated that stock markets are adversely effected by rising political tension in both domestic markets and in the international arena.

Although a large body of literature has associated the decline of the Venezuelan economy and financial system with political factors (see Vera 2015; Bolton 2016; Littman 2016; Merke and Feldmann 2016; Cannon and Brown 2017; Dachevsky and Kornblihtt 2017; Buxton 2018), the authors are not aware of any studies that have attempted to evaluate this association quantitatively using modern econometric techniques. In other words, it remains unclear in empirical terms whether and to what extent political risk has affected the financial risk in Venezuela. Therefore, the main innovation of the present study is that it fills this gap in the literature by establishing time-series-based models to explore the causal effect of political risk on the economic and financial risks in Venezuela using the wavelet coherence approach. Thus, it is anticipated that this study will initiate a new debate about the concept and the empirical findings derived from the modern econometrics technique will provide remarkable implications for the policymakers in Venezuela. Since the present study employs the wavelet coherence approach, it allows both the short-run and long-run causal effects of political risk on the economic and financial risks in Venezuela to be captured. The Venezuelan economy has been characterized by volatility and various economic shocks resulting from decreasing oil prices and mismanagement (bad governance). Table 1 presents the major political and economic events in Venezuela that have occurred over the period 1985-2018.

\section{Data and methodology}

Since the main innovation of this study is that it investigates the time-frequency dependency of political risk, financial risk, and economic risk in Venezuela, a distinctive dataset is used - the political risk index, financial risk index and economic risk indexsourced from the Political Risk Services (PRS). While the financial and economic risk 
Table 1 Major political and economic events in Venezuela (1985-2018) (source: BBC)

\begin{tabular}{|c|c|}
\hline Year, nature & Major political and economic events \\
\hline 1989, Election and Internal Conflict & $\begin{array}{l}\text { Carlos Andres Perez elected as president and implemented an } \\
\text { austerity programme with the IMF. Hundreds killed in street } \\
\text { violence and protests }\end{array}$ \\
\hline 1992, Internal Conflict & $\begin{array}{l}\text { Over } 100 \text { people killed in two coup attempts and Colonel Hugo } \\
\text { Chavez (Col Chavez) jailed for } 2 \text { years }\end{array}$ \\
\hline 1993-1995, Internal Conflict & President Perez impeached on corruption charges \\
\hline 1998, Change in the system & $\begin{array}{l}\text { Bolivarian Revolution implemented and Hugo Chavez elected } \\
\text { as president }\end{array}$ \\
\hline 2001, Reform & $\begin{array}{l}\text { President Chavez used Enabling Act to pass laws aimed at redis- } \\
\text { tributing land and wealth }\end{array}$ \\
\hline 2002, Military intervention & Unsuccessful coup attempt \\
\hline 2004, Referendum & No change in presidency \\
\hline 2005, Land Reform & $\begin{array}{l}\text { New land reform implemented to eliminate Venezuela's large } \\
\text { estates and to benefit the poor in rural areas }\end{array}$ \\
\hline 2006, International conflict & Chavez signed arms deal with Russia \\
\hline 2006, Election & $\begin{array}{l}\text { Chavez won the presidential election receiving almost } 2 / 3 \text { of } \\
\text { the total votes }\end{array}$ \\
\hline 2007, Economic conflict & $\begin{array}{l}\text { Nationalization programme is launched under the leadership } \\
\text { of President Chavez. In addition, rising conflict between the } \\
\text { government and US oil companies, namely Exxon Mobil and } \\
\text { Conoco Philips }\end{array}$ \\
\hline 2008, International conflict & $\begin{array}{l}\text { Venezuela and Russia signed an oil and gas cooperation agree- } \\
\text { ment. Moreover, they expanded this agreement with nuclear } \\
\text { cooperation }\end{array}$ \\
\hline 2010, Currency devaluation & Devaluation of the Bolivar currency \\
\hline 2010, Election & Opposition made significant gains \\
\hline 2012, Violation of financial and media freedom & $\begin{array}{l}\text { Government extended price controls on essential goods and } \\
\text { services to deal with inflation }\end{array}$ \\
\hline 2012, Election & 4th victory of Hugo Chavez in the presidential election \\
\hline 2013, Presidential change & $\begin{array}{l}\text { Nicolas Maduro was elected president after Hugo Chavez died } \\
\text { at the age of } 58\end{array}$ \\
\hline 2013, High inflation & High inflation \\
\hline 2014, Political protest & 28 people died in street violence \\
\hline 2015, Parliamentary change & $\begin{array}{l}\text { Opposition Democratic Unity won a majority in the parliament } \\
\text { but in } 2016, \text { three deputies from the Unity party resigned and } \\
\text { Maduro continued to rule the country }\end{array}$ \\
\hline 2016, Political protest & $\begin{array}{l}\text { Hundreds of thousands of people took part in a protest in Cara- } \\
\text { cas calling for the removal of President Maduro, accusing him } \\
\text { of being responsible for the economic crisis }\end{array}$ \\
\hline 2017, Internal and external conflict & $\begin{array}{l}\text { Controversial constituent assembly elected in the face of an } \\
\text { opposition boycott and international condemnation }\end{array}$ \\
\hline 2018, Internal conflict & $\begin{array}{l}\text { Opposition contests the official victory of President Maduro in } \\
\text { the presidential elections }\end{array}$ \\
\hline
\end{tabular}

indexes are constructed on the basis of 5 components, the political risk index is constructed by 12 components. The scores for the economic risk index and financial risk index range from 0 to 50, where 0 indicates a very high-risk environment, and a score of 50 points indicates a very low-risk environment. However, the score of the political risk index ranges between 0 and 100. The descriptive statistics of the financial risk and economic risk variables as well as their codes are presented in Table 2.

Figure 1 illustrates the political risk, financial risk and economic risk indexes for the case of Venezuela over the period from 1984 to 2018 on a quarterly basis. Undoubtedly, 
Table 2 Data and descriptive statistics

\begin{tabular}{llll}
\hline Data & Political Risk Index & Financial Risk Index & $\begin{array}{l}\text { Economic } \\
\text { Risk Index }\end{array}$ \\
\hline Source & PRS & PRS & PRS \\
Code & PRI & FRI & ERI \\
Time & $1984 \mathrm{Q} 1-2018 \mathrm{Q} 4$ & & \\
Mean & 56.248 & 37.264 & 26.471 \\
Median & 56.583 & 37.000 & 26.066 \\
Maximum & 76.000 & 46.500 & 41.500 \\
Minimum & 26.000 & 25.500 & 12.500 \\
\hline
\end{tabular}

PRS Political Risk Services Group

Denotes 5\% statistically significant level

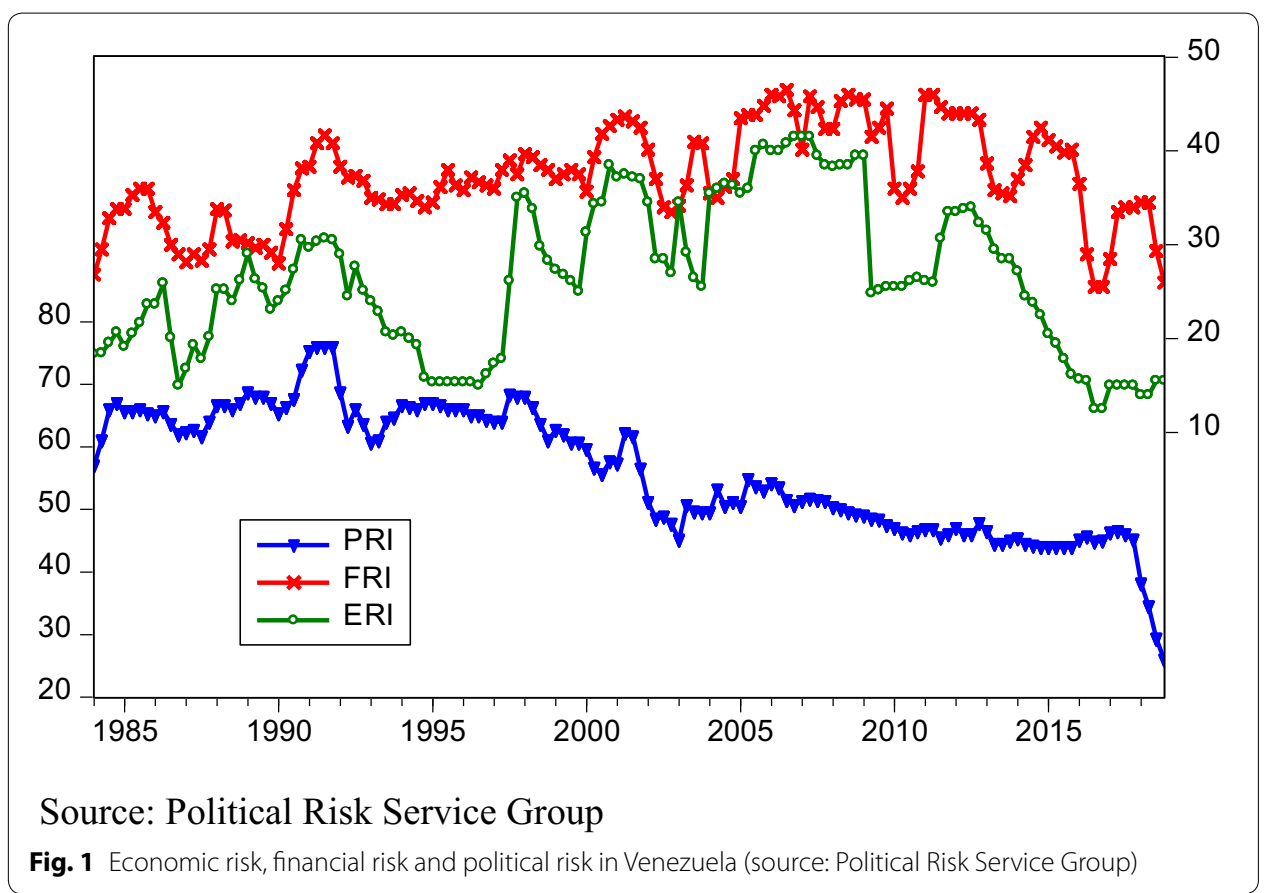

the performance of Venezuela in terms of political, economic and financial risks was vulnerable. As shown in Fig. 1, Venezuela was in a position of moderate risk in regard to the political environment between 1985 and 1998. However, under the presidency of both Hugo Chavez and Nicolas Maduro-the period between 1998 and 2018-the political risk index in Venezuela deteriorated; in fact, the performance of Venezuela with regard to political risk was the poorest among Latin American countries. In terms of economic and financial risk indexes over the period of 1985-2018, the economic environment in Venezuela was better in comparison to the financial conditions. However, from 2012 onwards, economic risk and financial risk indexes in Venezuela experienced a downward trend due to the global crisis, political vulnerabilities in the country, the reduction in the Venezuelan credit rating, high inflation and internal protests. These factors clearly indicate why the economic performance and financial system deteriorated in Venezuela. In 2018, Venezuela found itself in a position of high risk with regard to the economic 
environment and very high risk with regard to the financial environment. Therefore, Fig. 1 clearly illustrates the negative effect of rising political uncertainty in Venezuela on both financial and economic risks. Moreover, rising political tension in Venezuela moved economic and financial risk levels from a moderate to a very high-risk environment.

The present study investigates the time-frequency relationship between political risk, financial risk and economic risk in Venezuela using the wavelet approach initially developed by Goupillaud et al. (1984). Therefore, this allows the present study to determine whether the political vulnerability in Venezuela significantly caused economic and financial instabilities. "The main innovation of the wavelet techniques appears where the decomposition of one-dimensional time data into the bi-dimensional time-frequency sphere is allowed" (Kalmaz and Kirikkaleli 2019). This allows the identification of both the long- and short-run relationship among the time-series variables. A multi-scale decomposition method brings out a natural framework to show frequency-dependent behaviour for exploring the connection between political risk, economic risk and financial risk in Venezuela.

The present study uses a wavelet $(\psi)$ approach, which is a part of the Morlet wavelet family. The simple equation of $\psi$ is as follows:

$$
\psi(t)=\pi^{-\frac{1}{4}} e^{-i \omega_{0} t} e^{-\frac{1}{2} t^{2}}, \quad p(t), \quad t=1,2,3, \ldots, T ;
$$

where "frequency, represented by $(f)$, and time or location, represented by $(k)$, are the main parameters of the wavelet. While a wavelet's particular location in time is the fundamental character of the $k$ parameter, the frequency parameter controls the distended wavelet for localizing various frequencies. By transforming the wavelet equation, $\psi_{k, f}$ can first be constructed" (Kirikkaleli and Gokmenoglu 2019). The equation of the wavelet is transformed by adding frequency and location parameters, as shown in Eq. 1:

$$
\psi_{k, f}(t)=\frac{1}{\sqrt{h}} \psi\left(\frac{t-k}{f}\right), \quad k, f \in \mathbb{R}, f \neq 0 .
$$

After adding the time-series data $p(t)$, the equation of continuous wavelet function is as follows:

$$
W_{p}(k, f)=\int_{-\infty}^{\infty} p(t) \frac{1}{\sqrt{f}} \psi\left(\overline{\frac{t-k}{f}}\right) \mathrm{d} t .
$$

Equation 2 is regenerated as Eq. 3 after adding the coefficient $\psi$ to the equation:

$$
p(t)=\frac{1}{C_{\psi}} \int_{0}^{\infty}\left[\int_{-\infty}^{\infty}\left|W_{p}(a, b)\right|^{2} \mathrm{~d} a\right] \frac{\mathrm{d} b}{b^{2}} .
$$

To detect the vulnerability of economic, financial and political risk in Venezuela, the wavelet power spectrum (WPS) is used in the present study.

$$
\operatorname{WPS}_{p}(k, f)=\left|W_{p}(k, f)\right|^{2} .
$$

In the next step, the time-series variable is transformed by the cross-wavelet transform (CWT) approach, as presented in Eq. 5 below; 


$$
W_{p q}(k, f)=W_{p}(k, f) \overline{W_{q}(k, f)},
$$

where $W_{p}(k, f)$ and $W_{q}(k, f)$ indicate the CWT of two time-series variables (Alola and Kirikkaleli 2019). The equation of the squared wavelet coherence is as follows:

$$
R^{2}(k, f)=\frac{\left|C\left(f^{-1} W_{p q}(k, f)\right)\right|^{2}}{C\left(f^{-1}\left|W_{p}(k, f)\right|^{2}\right) C\left(f^{-1}\left|W_{q}(k, f)\right|^{2}\right)},
$$

where $R^{2}(k, f)$ ranges between 0 and 1 . Whenever $R^{2}(k, f)$ approaches 1 , it indicates that the time-series variables are correlated at a particular scale, which is surrounded by a black line and depicted by a red colour. On the other hand, when the value of $R^{2}(k, f)$ approaches 0 , it indicates that there is no correlation between the time-series variables and is denoted by the colour blue (Kirikkaleli 2019 and Alola and Kirikkaleli 2019).

However, obtaining the value of $R^{2}(k, f)$ does not provide any way of distinguishing between positive and negative correlations; thus "Torrence and Compo (1998) postulated a means by which to detect the wavelet coherence differences through indications of deferrals in the wavering of two time series" (Pal and Mitra 2017). The equation of the wavelet coherence approach is constructed as follows:

$$
\phi_{p q}(k, f)=\tan ^{-1}\left(\frac{L\left\{C\left(f^{-1} W_{p q}(k, f)\right)\right\}}{O\left\{C\left(f^{-1} W_{p q}(k, f)\right)\right\}}\right),
$$

where $L$ and $O$ denote an imaginary operator and a real part operator, respectively.

\section{Empirical findings}

In the present study, to identify the behaviour of the country risk indices, namely economic risk, financial risk and political risk, and to capture the time-frequency dependency of (i) political risk and economic risk and (ii) political risk and financial risk in Venezuela over the period from 1985 to 2018 on a quarterly basis, wavelet power spectrum and wavelet coherence techniques are employed. With reference to Figs. 2, 3 and 4, "the white curve corresponds to the cone of influence referring an edge under which the wavelet power is discontinued, and therefore hard to infer. The thick black contours refer to the wavelet power spectrum, significant at the five percent level, where significance test results are obtained by the means of Monte Carlo simulations. The colour referring to the power spectrum varies from red (strong) to blue (weak)." (Hamdi et al. 2019, page 175). With reference to Figs. 2, 3 and 4, all country risk indices exhibit some commonality in terms of the wavelet power spectrum. As can clearly be observed, the indices are significantly vulnerable, but at different time periods and frequency levels. During the global crisis period in 2008-2009, the financial and economic risk indexes in Venezuela exhibited high power. Figure 4 portrays that there was no vulnerability observed in the political risk index in Venezuela between 2003 and 2013; this was due to continuously rising political tension in Venezuela, as shown in Fig. 1. However, between 2013 and 2018, it is clear that there was significant vulnerability in the political risk index due to significantly rising political tensions during the Maduro Presidency. 


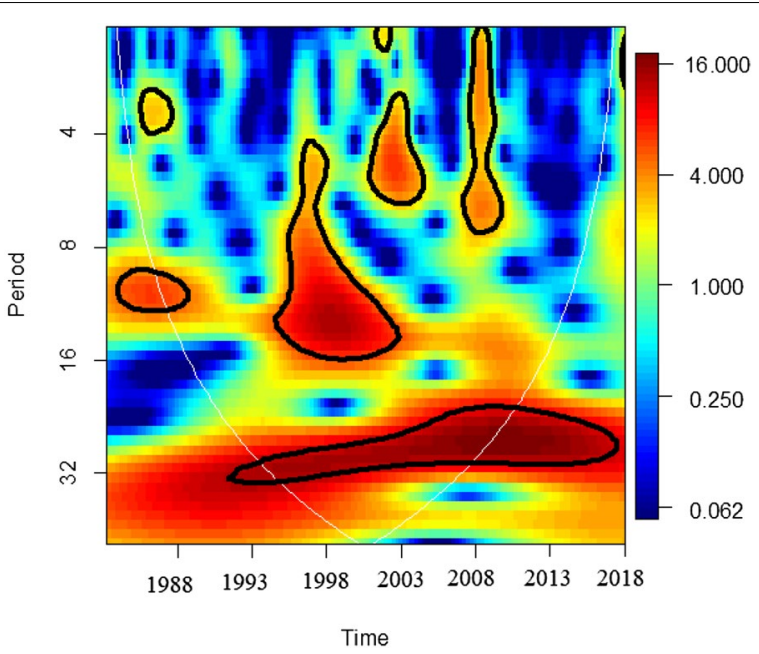

Fig. 2 Wavelet power spectrum for ERI

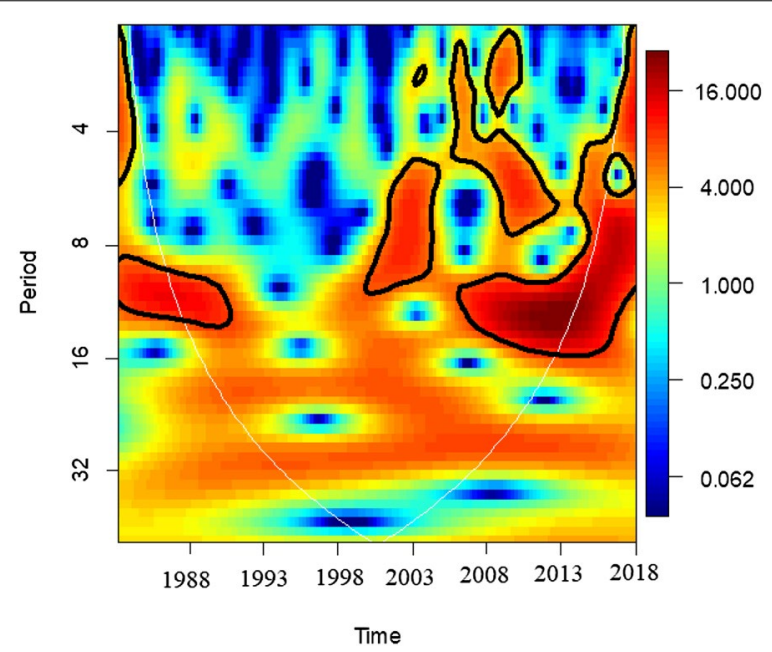

Fig. 3 Wavelet power spectrum for FRI

To capture the causal effect of political risk on financial and economic risks in Venezuela over the period from 1984Q1 to 2018Q4, the wavelet coherence technique is applied in this study and the findings for this approach are illustrated in Figs. 5, 6. The approach, derived from mathematics, combines information about both time and frequency domain causality approaches to obtain previously hidden information. Thus, the present study allows both short-run and long-run causal linkages between political risk and economic and financial risks in Venezuela to be captured. It is important to mention that since the wavelet coherence approach works well if data are noisy, nonstationary, and have several volatility shifts and structural breaks, the political risk, economic risk and financial risk variables are used at levels in the wavelet-based models. While cold (blue) represents no correlation among the variables in Figs. 5, 6, warmer coloured areas denote high dependency among the variables. In the wavelet coherence analysis, the direction of the significant causality is represented by arrows surrounded by the 


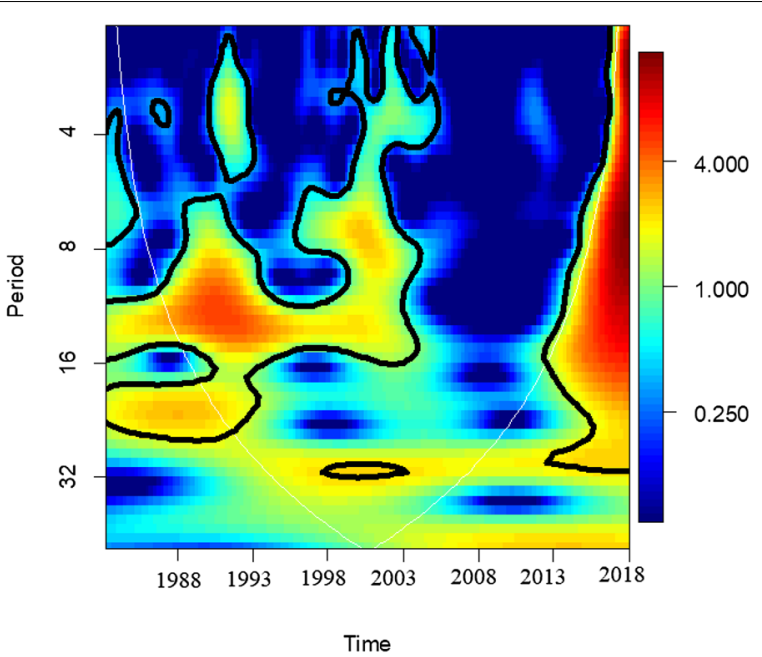

Fig. 4 Wavelet power spectrum for PRI

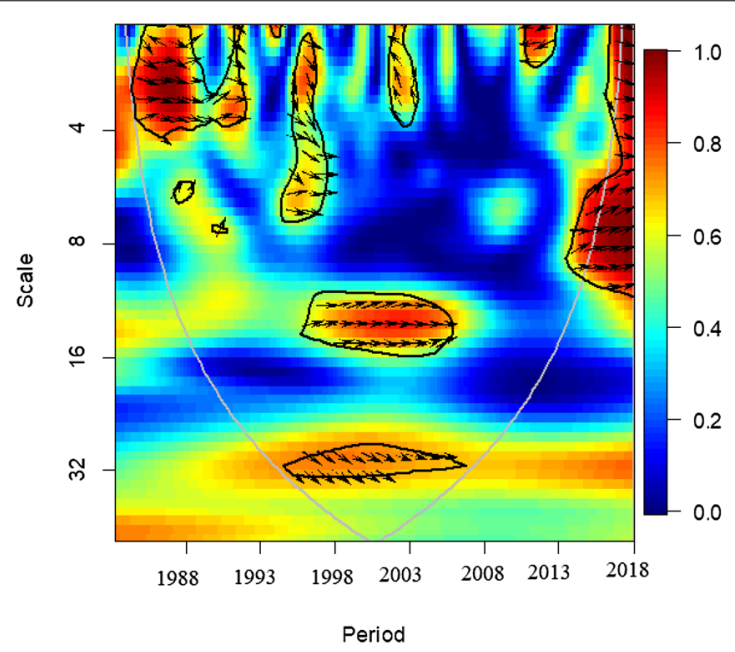

Fig. 5 Wavelet coherence between PRI and ERI

thick black line. While arrows pointing to the left indicate negative correlations among the variables, arrows pointing to the right represent positive correlations. In addition, arrows pointing to the up, right-up or left-down show that the second variable causes the first variable, whereas arrows pointing to the down, right-down or left-up indicate that changes in the first variable significantly lead to changes in the second variable. With reference to Fig. 5, as the arrows are pointing rightward and downright between 1998 and 2008 at different frequency levels, this indicates that economic risk and political risk are in phase. Moreover, as those arrows are pointing downright between 1994 and 2008 at relatively long-term scales (low frequencies), meaning that the economic risk index is led by the political risk index, this indicates that political risk is an important predictor for economic risk in Venezuela. As can be seen in Fig. 6, in the long run (low frequencies), the rightward pointing arrows indicate that changes in political risk in Venezuela lead to changes in financial risk. The main difference among the figures is the 


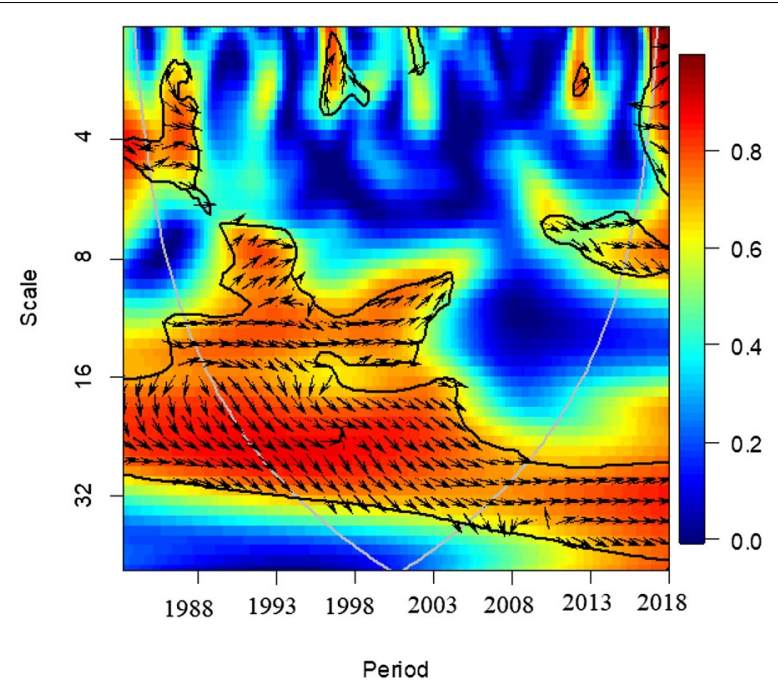

Fig. 6 Wavelet coherence between PRI and FRI

colour difference or strength of the correlation in the white cone-shaped curve. In other words, the correlation between financial risk and political risk is greater than the correlation between economic risk and political risk, indicating that political risk significantly effects Venezuela`s ability to pay her debts.

\section{Conclusion}

Although there is a consensus on the adverse effect of political instability on economic and financial dynamics in Venezuela, no previous studies have empirically examined the effect of political risk on economic and financial risks using the wavelet approach, which allows this study to explore both the long- and short-term causal relationship between political risk and economic and financial risks in Venezuela over the period of 1985Q1 to 2018Q4. The outcomes of this study reveal that significant vulnerabilities in political risk, economic risk, and financial risk are observed at different time periods and different frequency levels. Moreover, the present study also underlines the importance of political risk for predicting economic risk, since the empirical results reveal that political risk holds a strong power for explaining economic risk from 1995 to 2005 in the long run, whereas between 1984 and 2010, economic risk and political risk are positively correlated at different frequency levels. Finally, in the long run, the outcomes of this study show that changes in political risk significantly lead to changes in financial risk in Venezuela. Therefore, policymakers in Venezuela should control political tension in the country in order to achieve sustainable growth and obtain a sound financial system. Despite providing strong and consistent empirical outcomes for the case of Venezuela, further research should consider how this argument can be advanced by focusing on different developing countries.

Acknowledgements

Not applicable.

Authors' contributions

The author read and approved the final manuscript. 


\section{Funding}

I also confirmed that this research did not receive any specific grant from funding agencies in the public, commercial, or not-for-profit sectors.

\section{Availability of data and materials}

The data that support the findings of this study are available from the Political Risk Services Group but restrictions apply to the availability of these data, which were used under license for the current study, and so are not publicly available. Data are however available from the authors upon reasonable request and with permission of Political Risk Services Group.

\section{Competing interests}

The author declares no competing interests.

Received: 27 October 2019 Revised: 10 January 2020 Accepted: 18 January 2020

Published online: 27 January 2020

\section{References}

Alexakis P, Petrakis P (1991) Analysing stock market behaviour in a small capital market. J Bank Financ 15(3):471-483

Alola AA, Kirikkaleli D (2019) The nexus of environmental quality with renewable consumption, immigration, and healthcare in the US: wavelet and gradual-shift causality approaches. Environ Sci Pollut Res 26(34):35208-35217

Asteriou D, Price S (2001) Political instability and economic growth: UK time series evidence. Scott J Polit Econ 48(4):383-399

Barro RJ (1991) A cross-country study of growth, saving, and government. In: National saving and economic performance. University of Chicago Press, Chicago, pp 271-304

Bolton P (2016) The other explanation for Venezuela's economic crisis. Council on Hemispheric Affairs, Washington, DC Buxton J (2018) The failure of political reform in Venezuela. Routledge, London

Cannon B, Brown J (2017) Venezuela 2016: the year of living dangerously. Revista de Ciencia Política. 37(2):613-633

Chan YC, Wei KJ (1996) Political risk and stock price volatility: the case of Hong Kong. Pac Basin Financ J 4(2-3):259-275

Charfeddine L, Al Refai H (2019) Political tensions, stock market dependence and volatility spillover: evidence from the recent intra-GCC crises. N Am J Econ Financ 50:101032

Dachevsky F, Kornblihtt J (2017) The reproduction and crisis of capitalism in Venezuela under Chavismo. Latin Am Perspect 44(1):78-93

Goupillaud P, Grossmann A, Morlet J (1984) Cycle-octave and related transforms in seismic signal analysis. Geoexploration 23(1):85-102

Gunay S (2016) Is political risk still an issue for Turkish stock market? Borsa Istanb Rev 16(1):21-31

Hamdi B, Aloui M, Alqahtani F, Tiwari A (2019) Relationship between the oil price volatility and sectoral stock markets in oil-exporting economies: evidence from wavelet nonlinear denoised based quantile and Granger-causality analysis. Energy Econ 80:536-552

Hillier D, Loncan T (2019) Political uncertainty and stock returns: evidence from the Brazilian political crisis. Pac Basin Financ J 54:1-2

Kalmaz DB, Kirikkaleli D (2019) Modeling $\mathrm{CO}_{2}$ emissions in an emerging market: empirical finding from ARDL-based bounds and wavelet coherence approaches. Environ Sci Pollut Res 26(5):5210-5220

Kirikkaleli D (2019) Time-frequency dependency of financial risk and economic risk: evidence from Greece. J Econ Struct 8(1):37

Kirikkaleli D, Gokmenoglu KK (2019) Sovereign credit risk and economic risk in Turkey: empirical evidence from a wavelet coherence approach. Borsa Istanbul Review

Littman M (2016) State failure in Venezuela

Merke F and Feldmann AE (2016) Venezuela on the Edge: Can the Region Help? O della Costa Stuenke

Murad MS, Alshyab N (2019) Political instability and its impact on economic growth: the case of Jordan. Int J Dev Issues 18(3):366-380

Okafor $G$ (2017) The impact of political instability on the economic growth of ECOWAS member countries. Def Peace Econ 28(2):208-229

Pal D, Mitra SK (2017) Time-frequency contained co-movement of crude oil and world food prices: a wavelet-based analysis. Energy Econ 62:230-239

Sweidan OD (2016) Political instability and economic growth: evidence from Jordan. Rev Middle East Econ Financ 12(3):279-300

Tabassam AH, Hashmi SH, Rehman FU (2016) Nexus between political instability and economic growth in Pakistan. Procedia Soc Behav Sci 230:325-334

Torrence C, Compo GP (1998) A practical guide to wavelet analysis. Bull Am Meteorol Soc 79(1):61-78

Vera L (2015) Venezuela 1999-2014: macro-policy, oil governance and economic performance. Comp Econ Stud 57(3):539-568

Wang H (2019) The causality link between political risk and stock prices: a counterfactual study in an emerging market. J Financ Econ Policy 11(3):338-367

\section{Publisher's Note}

Springer Nature remains neutral with regard to jurisdictional claims in published maps and institutional affiliations. 